УДК 342.9

DOI https://doi.org/10.32837/pyuv.v2i4(29).430

\author{
Я.Я.Сташків \\ orcid.org/0000-0001-5547-9125 \\ ад'юнкт відділу докторантури та ад'юнктури \\ Наиіональної академії внутрішніх справ
}

\title{
ПРИНЦИПИ ДІЯЛЬНОСТІ СЛУЖБИ ДІЛЬНИЧНИХ ОФІЦЕРІВ ПОЛІЦІЇ ТА ЇХ ПРОФІЛАКТИЧНА СПРЯМОВАНІСТЬ
}

Постановка проблеми. Щоб отримати загальне уявлення про сутність і зміст профілактичної діяльності дільничних офіцерів поліції (далі ДОП), в обов'язковому порядку необхідно проаналізувати основні принципи такої діяльності, що визначають її спрямованість, тобто основні вихідні положення, на яких вона повинна грунтуватись і яким повинна відповідати. Як свідчить аналіз результатів проведеного нами дослідження, в останні роки аналіз принципів функціонування будь-якого органу чи його структурного підрозділу став традиційним. Це зумовлено, зокрема, тим, що питання про принципи - це питання про характер і межі втручання ДОП у приватне життя громадян. Крім того, саме через аналіз принципів можна виявити основні прогалини в структурно-функціональній будові службби ДОП і на цій основі розробити пропозиції щодо їх усунення.

3 огляду на викладене основною метою даної наукової статті $\mathbf{\epsilon}$ аналіз нормативно закріпленої системи принципів діяльності дільничних офіцерів поліції, з'ясування обгрунтованості включення до неї окремих принципів, а також обгрунтування пропозицій з її удосконалення.

Виклад основного змісту. 3'ясуємо, що необхідно розуміти під принципами діяльності служби ДОП. Щоб дати відповідь на це питання, необхідно звернутись до наукової літератури. Нам вдалося з'ясувати, що слово «принцип» має латинське походження й в найбільш загальному розумінні означає «початок, основа».

Таке широке тлумачення даного терміна призвело до того, що в науковій літературі з'явилось безліч його трактувань. Їх аналіз, порівняння та екстраполяція на діяльність ДоП дозволили нам акцентувати увагу на таких характерних особливостях.

По-перше, принципи профілактичної діяльності ДОП - це ідейні початки, що тісно пов'язані з державною політикою у сфері профілактики правопорушень. Вони відображають основні ідеї, цілі та задачі такої політики, а також способи реалізації та здійснення основних профілактичних заходів.

По-друге, такі принципи - це загальні, вихідні положення та ідеї, які мають цементуюче значення для профілактичної діяльності служби ДоП. Вони не лише визначають іï спрямованість, будо- ву, форму та зміст заходів, а й уособлюють загальні закономірності розвитку служби ДОП, слугують ключем до розуміння сутності та специфіки iї діяльності, структури та місця в системі органів та підрозділів поліції.

По-третє, принципи визначають межі втручання дільничних в особисте життя особи, тому вони мають значення не лише для регулювання профілактичної діяльності ДоП, а й для захисту прав і свобод громадян.

По-четверте, принципи діють на всіх стадіях та етапах профілактичної діяльності ДОП, а також поширюють свій регулятивний вплив на всіх суб'єктів, залучених до цього процесу.

По-п'яте, як основні й центральні положення, на яких будується профілактична діяльність ДОП, принципи існують у формі правових норм. Ïx дотримання і виконання є обов'язковим для всіх працівників.

По-шосте, як нормативні розпорядження принципи мають бути дієвими, тому в тексті будь-якого правового акта їх зміст підлягає найбільш повному розкриттю. Цілісність і початковий зміст принципів має бути незалежним від зміни, доповнення чи скасування окремих нормативно-правових актів. Усі інші норми, закріплені в таких актах, повинні бути узгоджені та жорстко прив'язані до принципів.

По-сьоме, принципи - це загальновизнані положення, тому їм властива нормативність, незаперечність, загальнообов'язковість, потенційна можливість їх дотримання за допомогою заходів державного примусу.

По-восьме, принципи профілактичної діяльності служби ДОП забезпечують взаємодію та взаємоузгодження всіх іiі структурних елементів як між собою, так із системами вищого рівня. Вони забезпечують збалансованість, усувають протиріччя, створюють передумови для інтеграції та одночасної диференціації різних напрямів діяльності ДОП.

Узагальнюючи викладені вище ознаки, ми можемо сформулювати таке визначення. Принципи профілактичної діяльності ДОП - це закріплені в нормах права, науково обгрунтовані та апробовані практикою основні засади, які найбільш повно визначають сутність і характер діяльності ДОП, поширюють свій вплив на всі стадії, етапи 
та рівні профілактичного процесу та спрямовані на забезпечення його результативності.

Принципи права взагалі та принципи профілактичної діяльності зокрема неможливо розглядати у відриві одні від інших, тобто без урахування їх взаємопов'язаності та взаємозумовленості. У своїй сукупності такі принципи повинні утворювати чітку систему основних засад, що не суперечать одна одній та після закріплення в чинному законодавстві оформлюються як явища правової реальності. Однак відносно діяльності ДОП важко говорити про якусь стійку систему принципів. Чинна на сьогодні Інструкція включає до цієї системи лише такі принципи, як верховенство права, дотримання прав і свобод людини, законності, відкритості та прозорості, політичної нейтральності, взаємодії з населенням на засадах партнерства [1]. Хоча порівняно з Наказом МВС України № 550 дана система була дещо видозмінена (раніше діяльність служби ДІМ грунтувалась на принципах законності, гуманізму, поваги до особи, соціальної справедливості, взаємодії з трудовими колективами, громадськими організаціями й населенням, незалежності від діяльності політичних партій та інших громадських об'єднань [2]), однак її все ще зарано вважати такою, що відображає усю специфіку дальності ДОП і її профілактичну спрямованість. Неважко помітити, що вона практично ідентична системі принципів діяльності Національної поліції, яка закріплена в ст.ст. 6-11 Закону України «Про Національну поліцію», за винятком принципу безперервності, який не був включений в систему принципів діяльності ДОП [3].

Відразу ж зауважимо, що ми категорично заперечуємо обгрунтованість і доцільність такого автоматичного перенесення принципів діяльності всієї поліції на сферу функціонування ДОП, яка, як відомо, характеризується певною специфікою і має чітко виражену профілактичну спрямованість. Так, проаналізувавши практичну діяльність служб ДОП на різних рівнях, ми дійшли висновку, що в більшій чи меншій мірі всі працівники служби ДОП виконують покладені на них повноваження, дотримуючись таких основних принципів: об'єктивності, демократизму, гуманізму та соціальної справедливості, наукової обгрунтованості, економічної доцільності, комплексності, організованості, ефективності, координованості, системності, стійкої диференціації, поєднання гласності та професійної таємниці, централізації та децентралізації, постійного врахування громадської думки, взаємодії з населенням, своєчасності, мобільності та оперативності, організованості, достатності, точності та конкретності, професіоналізму та компетентності, відповідальності влади та посадових осіб за розробку, реалізацію та наслідки профілактичної діяльності тощо.
Однак, попри всю важливість наведених правових засад, не варто поспішати та переводити їх у ранг правових принципів, адже відомо, що чим більше принципів, тим менше їх значення, тим більша їх розмитість. Принципи діяльності служби ДОП є фундаментом, на якому мають будуватися правила діяльності для всіх їі працівників, тому їх має бути рівно стільки, скільки вимагають умови служби.

Зокрема, діяльність ДОП має бути законною. У нашому випадку дотримання принципу законності передбачає таке:

1) верховенство Конституції, законів та ратифікованих міжнародно-правових актів над іншими підзаконними актами, наказами та посадовими інструкціями, що регламентують діяльність ДОП;

2) сувору відповідність діяльності ДОП вимогам законодавства, компетенції служби ДОП та наданим повноваженням;

3) відповідність профілактичних заходів, які застосовуються ДОП, загальним демократичним принципам права, чинному законодавству та загальновизнаним міжнародним стандартам;

4) застосування профілактичних заходів лише за наявності фактичних обставин, які передбачені в нормативно-правових актах, а також при неухильному дотриманні гарантій прав і законних інтересів осіб, щодо яких вони застосовуються;

5) чітке визначення та нормативне закріплення не лише завдань і функцій служби ДОП, а й повноважень її працівників, що дозволяє уникнути дублювання їх завдань і функцій;

6) безпосередню участь в діяльності ДОП і контроль за нею не лише з боку представницьких органів влади відповідного рівня, а й з боку ЗMI, громадськості та окремих громадян тощо.

3 викладеного випливає, що законність є основним принципом профілактичної діяльності служби ДОП та найважливішою умовою ефективного виконання покладених на неї завдань. При цьому реалізація даного принципу спрямована не лише на підтримання режиму законності в державі, а й на викорінення свавілля та вседозволеності дільничних.

Основоположне значення в діяльності служби ДОП відводиться також принципам гуланізлу, поваги до особи та соиіальної справедливості. Це зумовлено іï призначенням та особливою роллю у профілактиці правопорушень. По-перше, діяльність ДОП є відкритою та гласною, що відіграє вирішальну роль при формуванні громадської думки про поліцію взагалі. По-друге, під час виконання своїх обов'язків ДОП взаємодіють 3 широкими верствами населення та досить часто 3 громадянами, які не порушують громадський порядок і звертаються до поліції з метою 
отримання роз'яснень, управлінських чи соціальних послуг.

Викладені вище обставини призвели до того, що служба ДОП була вимушена змінити свій імідж і переформатувати свою діяльність із каральної в соціально-профілактичну. Такі зміни торкнулись і змісту аналізованих принципів, які набули такого змісту:

1) ДОП в межах своєї компетенції вживають заходів щодо охорони життя та здоров' я громадян, їх власності від протиправних посягань, техногенних аварій та природних катастроф, надають допомогу потерпілим від правопорушень, нещасних випадків і надзвичайних ситуацій тощо;

2) пріоритетом діяльності ДОП є не розслідування протиправних посягань і притягнення винних до відповідальності, а їх профілактика, а також соціальна, корекційна, виховна та інформаційна робота;

3) при застосуванні заходів профілактичного впливу ДОП застосовують методи, які є адекватними в конкретній ситуації, не допускають їх надлишкової інтенсивності, заподіяння фізичних і моральних страждань, приниження честі та людської гідності [4, с. 116];

4) кожний дільничний незалежно від звання та посади зобов' язаний чуйно та уважно ставитись до громадян. Неприпустимими вважаються будьякі випадки приниження людської гідності, обману, насильства тощо;

5) якщо застосування тих чи інших профілактичних заходів не передбачене чинним законодавством, при їх здійсненні дільничні керуються нормами службової етики співробітника поліції, загальноправовими і моральними принципами.

Дільничні офіцери поліції здійснюють заходи, спрямовані на профілактику протиправних посягань, із обов'язковим дотриманням принципу об’єктивності. Це зумовлено тим, що така діяльність має соціальну природу і протікає відповідно до об'єктивних законів розвитку суспільства.

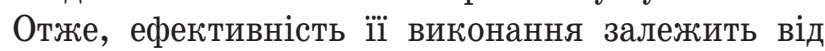
того, наскільки дільничні пізнають такі закони, свідомо їх використовують, беруть до уваги реальні можливості та фактичний стан справ. 3 огляду на це необхідно виділити відразу декілька складників аналізованого принципу.

По-перше, діяльність ДОП має бути цілеспрямованою, тобто направленою на вирішення найбільш важливих профілактичних задач, послідовне та наполегливе досягнення запланованого.

По-друге, така діяльність має бути системною, тобто враховувати всі умови та фактори, що реально на неї впливають, поєднувати дії всіх суб’єктів профілактики та суб'єктів координуючих і контролюючих органів у цілісну цільову програму [5, с. 110].

По-третє, вона має бути комплексною. Це передбачає об’єднання в рамках профілактичної діяльності різноманітних заходів правового, організаційного, економічного, психолого-педагогічного та матеріально-технічного характеру, а також поєднання загальнопрофілактичних заходів із індивідуальним підходом.

По-четверте, діяльність ДОП має бути максимально ефективною та економічно доцільною, тобто передбачати досягнення поставлених завдань при найменших витратах часу, сил і засобів, а також оптимізацію прийнятих рішень, тобто розробку кількох варіанті вирішення поставлених завдань, їх зіставлення та вибір найбільш оптимального та раціонального.

По-п'яте, така діяльність повинна мати випереджальний характер, тобто застосовувані ДОП профілактичні заходи мають бути своєчасними, доцільними та достатніми. Це вимагає їх застосування на максимально ранньому етапі виникнення конфліктних ситуацій.

По-шосте, вона повинна бути мобільною та оперативною. Це вимагає постійної підтримки високого ступеня готовності до зміни оперативної обстановки, швидкого реагування на заяви та повідомлення про злочини та пригоди, своєчасного, якісного, гнучкого вирішення завдань різного ступеня складності.

По-сьоме, діяльність ДОП повинна бути організованою. Це проявляється в суворій впорядкованості всіх процесів управління профілактичною діяльністю, в їх систематичному перегляді, уточненні та узгодженні.

По-восьме, вона має бути точною. Це передбачає виконавчу дисципліну кожного дільничного, обов'язковість та однозначність наданих вказівок, обов' язковий контроль за їх виконанням, чітке планування всіх профілактичних заходів.

По-дев'яте, вона повинна бути конкретною, тобто такою, що відповідає реально існуючим криміногенним чинникам.

Не менш важливе значення в діяльності ДОП відводиться принципу наукового управління, який передбачає:

- використання таких форм, методів та засобів профілактичної діяльності, які розроблені та схвалені наукою;

- прогнозування, планування, управління та реалізацію профілактичних заходів на основі єдиної наукової концепції профілактики злочинності;

- застосування наукових методик збору та обробки інформації про характер та рівень злочинності;

- розробку механізму імплементації в практику профілактичної діяльності ДОП наукових рекомендацій;

- широке використання в практиці профілактичної діяльності здобутих наукою знань [6, с. 169]; 
- науково-методичне забезпечення діяльності ДОП на всіх рівнях і напрямах, комплексне використання в практичній діяльності теоретичних напрацювань.

Діяльність служби ДОП є гласною, що забезпечує її відкритість і прозорість, доступ громадян до прийнятих рішень та зближення з населенням. Сьогодні зміст даного принципу складають такі положення:

- своєчасне, повне та об'єктивне висвітлення відомостей про діяльність ДОП у сфері профілактики правопорушень;

- регулярне інформування населення про дійсний рівень злочинності у суспільстві, про стан та динаміку злочинності на закріпленій поліцейській дільниці, а також про всі вжиті заходи щодо її подолання;

- залучення громадськості та ЗМІ до всебічного обговорення проблем, які існують в житті територіальної громади, та можливих варіантів їх вирішення;

- встановлення громадського контролю за діяльністю ДОП, а також постійне вивчення та аналіз громадської думки тощо.

При цьому найбільш ефективним інструментом реалізації принципу гласності вважаються 3МI, залучення яких стимулює формування громадської думки, включення населення до профілактичної роботи, підвищує її активність та ефективність, сприяє формуванню позитивного іміджу ДОП.

Діяльність ДОП у сфері профілактики протиправних посягань здійснюється у тісній взаєлодії з іншили суб'єктали профілактики та водночас є політично нейтральною. Відомо, що профілактика правопорушень - це досить широка сфера суспільної діяльності, до якої залучаються не лише ДОП, але й інші підрозділи поліції, різноманітні правоохоронні органи, органи державної влади та місцевого самоврядування, підприємства, установи, організації, громадські об'єднання та формування, ЗМІ, церква, трудові колективи, громадськість та окремі громадяни, а також міжнародні організації та правоохоронні органи зарубіжних країн. Звісно, ефективність такої діяльності напряму залежить від спільних і узгоджених дій названих суб'єктів, їх спрямованості на досягнення спільної мети, надання взаємної допомоги при вирішенні окремих завдань, а також від планомірної реалізації всього комплексу профілактичних заходів. При цьому всі профілактичні заходи мають бути взаємопов' язаними та узгодженими, здійснюватись у межах однієї спрямованості і в своїй сукупності утворювати цілісну цільову програму профілактики правопорушень, у якій окремі суб'єкти функціонують як тісно пов'язані між собою елементи. Місце і роль кожного елемента має бути чітко прописані, щоб не допусти- ти безпідставного дублювання завдань і функцій, а також конфлікту інтересів.

Не менш важлива роль в діяльності служби ДОП має відводитись таким принципам, як прогнозованість $i$ плановість. Як відомо, злочинність - це явище соціальне, тому зміни в її структурі, динаміці та рівні відбуваються переважно під впливом об'єктивних законів розвитку суспільства та природи. Оскільки стихійність i випадковість займають лише незначну частку в даному явищі, воно може (і повинно) піддаватись постійному статистичному аналізу та науковому прогнозуванню. Отже, діяльність ДОП у сфері профілактики повинна бути організованою і плановою, грунтуватись на всебічному вивченні та аналізі основних показників злочинності, здійснюватись відповідно до нормативно затверджених профілактичних програм та планів. Головним $€$ те, що постійне вивчення громадської думки має лежати в основні планування будь-якого напряму профілактичної роботи ДОП.

Нарешті, профілактичну спрямованість діяльності служби ДОП важко собі уявити без принципу взаєлодї з населеннял на засадах партнерства. Відразу ж зауважимо, що принцип взаємодії з населенням не є новим в роботі дільничних і супроводжує їі ще з часів зародження цієї служби. Водночас після докорінного реформування поліції даний принцип набув нового звучання і відтоді розглядається у нерозривному зв'язку із партнерськими відносинами дільничного та громади.

Взаємодію поліції 3 населенням на засадах партнерства прийнято називати англійським терміном “Community Policing”. Вона передбачає постійну співпрацю поліції та місцевої влади з метою створення безпечного простору і грунтується на першочерговому врахуванні думки громади 3 питань забезпечення публічної безпеки та порядку. У ст. 11 Закону України «Про Національну поліцію» даний принцип визначається у контексті здійснення діяльності поліції в тісній співпраці та взаємодії з населенням, територіальними громадами та громадськими об'єднаннями на засадах партнерства [3]. У ч. 2 цієї ж статті підкреслюється профілактична спрямованість даного принципу. Зокрема, зазначається, що «з метою визначення причин та/або умов учинення правопорушень планування службової діяльності органів і підрозділів поліції здійснюється з урахуванням специфіки регіону та проблем територіальних громад» [3].

Принцип взаємодії з населенням на засадах партнерства - це єдиний принцип організації діяльності ДОП, який отримав розгорнуте визначення в новій Інструкції з організації діяльності ДОП. Зокрема, йому присвячено окремий розділ Наказу МВС України № 650 - Розділ III «Взаємодія 3 населенням» [1]. Знайомство із основними 
положеннями зазначеного розділу дозволило нам визначити такі основні напрями діяльності ДОП, спрямовані на впровадження принципу взаємодії з населенням на засадах партнерства: 1) протидію злочинності, профілактику правопорушень та охорону публічного порядку за участю населення; 2) співпрацю з органами місцевого самоврядування, представниками територіальних громад, населенням, керівниками підприємств, соціальних, навчальних та культурних закладів, закладів захисту дітей, обмін інформацією для подальшого її використання під час виконання службових обов'язків; 3) визначення спільних і пріоритетних напрямів роботи та їі оцінювання з урахуванням думки і потреб громадськості [1].

Проаналізувавши наведені вище напрями діяльності ДОП, ми дійшли висновку, що їх явно мало, аби повною мірою розкрити профілактичний потенціал принципу взаємодії з населенням на засадах партнерства. На нашу думку, яка грунтується на узагальненні практики діяльності ДОП, а також зарубіжного досвіду реалізації принципу Community Policing, їх перелік необхідно розширити за рахунок включення до нього таких напрямів:

- безпосередньої участі в розробці та реалізації місцевих програм, що передбачають спільну роботу ДОП і громадськості і спрямовані на розбудову безпечного середовища, здійснення поточного та перспективного планування діяльності ДОП з урахуванням положень таких програм;

- участі у створенні та підтриманні в актуальному стані інноваційних онлайн-платформ, інтерактивних карт злочинності та інших діалогових громадських ініціатив і проєктів, які дозволять громадянам отримувати актуальну інформацію про стан безпеки за місцем проживання, стан розгляду їх заяв та повідомлень, а також безпосередньо оцінювати роботу ДОП і поліції в цілому;

- об’єктивного, системного, своєчасного та послідовного інформування громадськості про стан оперативної обстановки на відповідній території, структуру, рівень і динаміку злочинності.

Практична реалізація зроблених нами висновків передбачає внесення змін до п. 1 Розділу III Наказу МВС України № 650 і доповнення його підпунктами 4-6 відповідного змісту.

Висновки. Підсумовуючи викладене вище, з усією очевидністю можна стверджувати, що система принципів діяльності ДОП, закріплена в Наказі МВС України № 650, не відображає профілактичну спрямованість діяльності цієї служби, тому вона має бути переглянута й доповнена. 3 цією метою ми пропонуємо внести зміни до п. 3 Розділу I Наказу, виклавши його в такій редакції: «3. ДОП здійснюють свою діяльність із дотриманням принципів законності, гуманізму, поваги до особи та соціальної справедливості, об’єктивності, наукового управління, гласності, взаємодії 3 іншими суб’єктами профілактики, політичної нейтральності, прогнозованості та плановості, взаємодії з населенням на засадах партнерства».

\section{Jimepamypa}

1. Про затвердження Інструкції з організації діяльності дільничних офіцерів поліції : Наказ МВС України від 28.07.2017 р. № 650 .

2. Про затвердження Положення про службу дільничних інспекторів міліції в системі Міністерства внутрішніх справ України : Наказ МВС України від 11.11 .2010 p. № 550.

3. Про Національну поліцію : Закон України від 02.07.2015 p.

4. Бугайчук К.Л. Адміністративні проступки: сутність та організаційно-правові заходи їх профілактики : дис. ... кандидата юрид. наук : 12.00.07. Харків : Національний університет внутрішніх справ України. 2002. $243 \mathrm{c}$.

5. Плішкін В.М. Теорія управління органами внутрішніх справ : підручник / за ред. канд. юрид. наук. Ю.Ф. Кравченка. Київ : Національна академія внутрішніх справ України, 1999. 702 с.

6. Быргэу M.M. Организация деятельности полиции Республики Молдова по профилактике преступлений : дисс. ... доктора юрид. наук : 12.00.07. Харьков : Национальный университет внутренних дел, 2004. 532 c.

\section{Анотація}

Сташків Я. Я. Принципи діяльності служби дільничних офіцерів поліції та ї профілактична спрямованість. - Стаття.

3'ясовується етимологічне значення слова «принцип», а також його тлумачення в науковій та енциклопедичній літературі і на основі проведеного дослідження формулюється авторська дефініція терміна «принципи профілактичної діяльності дільничних офіцерів поліції». Аналізується система принципів діяльності дільничних офіцерів поліції, яка закріплена в новій Інструкції з організації діяльності дільничних офіцерів поліції, і з урахуванням результатів проведеного аналізу обгрунтовуються пропозиції з їі удосконалення. Визначено, що законність є основним принципом профілактичної діяльності служби дільничних офіцерів поліції та найважливішою умовою ефективного виконання покладених на неї завдань. При цьому реалізація даного принципу спрямована не лише на підтримання режиму законності в державі, а і на викорінення свавілля та вседозволеності дільничних. 3'ясовано, що взаємодію поліції з населенням на засадах партнерства прийнято називати англійським терміном "Community Policing". Вона передбачає постійну співпрацю поліції та місцевої влади 3 метою створення безпечного простору і грунтується на першочерговому врахуванні думки громади з питань забезпечення публічної безпеки та порядку. Зроблено висновок, що, щоб у повній мірі розкрити профілактичний потенціал принципу взаємодії з населенням на засадах партнерства дільничних офіцерів поліції, необхідно розширити напрями діяльності і включити в них такі: безпосередню участь в розробці та реалізації місцевих програм, що передбачають спільну роботу дільничних офріцерів поліції і громадськості і спрямовані на розбудову безпечного середовища; здійснення поточного та перспективного планування діяльності дільничних офіцерів поліції з урахуванням положень 
таких програм; участь у створенні та підтриманні в актуальному стані інноваційних онлайн-платформ, інтерактивних карт злочинності та інших діалогових громадських ініціатив і проєктів, які дозволять громадянам отримувати актуальну інформацію про стан безпеки за місцем проживання, стан розгляду їх заяв та повідомлень, а також безпосередньо оцінювати роботу дільничних офіцерів поліції і поліції в цілому; об'єктивне, системне, своєчасне та послідовне інформування громадськості про стан оперативної обстановки на відповідній території, структуру, рівень і динаміку злочинності.

Ключові слова: взаємодія 3 іншими суб'єктами профілактики, взаємодія 3 населенням на засадах партнерства, гласність, гуманізм, дільничний офіцер поліції, законність, наукове управління, плановість, повага до особи, політична нейтральність, прогнозованість, принципи профілактичної діяльності, соціальна справедливість, об’єктивність.

\section{Summary}

Stashkiv Ya. Ya. The principles of activities of district police officers and their preventive focus. - Article.

The etymological meaning of the word "principle" as well as its interpretation in the scientific and encyclopedic literature is clarified and the author's definition of the term "principles of preventive activity of police officers" is formulated on the basis of the conducted research. The system of principles of activity of police officers, which is enshrined in the new Instruction on the organization of activities of police officers, is analyzed and proposals for its improvement are substantiated, taking into account the results of the analysis. It is determined that legality is the basic principle of preventive activity of the service of police officers and the most important condition for the effective fulfillment of the tasks assigned to it. At the same time, the implementation of this principle is aimed not only at maintaining the regime of legality in the state, but also at eradicating arbitrariness and permissiveness of precincts. It has been found that the partnership with the community on a partnership basis is commonly referred to as the English term "Community Policing". It envisages continuous cooperation between the police and local authorities in order to create a safe space and is based on a high priority for the public opinion on public safety and order. It is concluded that in order to fully unlock the preventive potential of the principle of interaction with the public on the basis of partnership of police officers, it is necessary to expand the following activities: direct participation in the development and implementation of local programs that involve the joint work of police officers of the community and the public and targeted; implementation of current and prospective planning of police officers' activities taking into account the provisions of such programs; participating in the creation and up-to-date state of innovative online platforms, interactive crime maps and other dialogue-driven civic initiatives and projects that allow citizens to receive upto-date information on their place of residence safety, the status of their applications and communications, and to evaluate directly the work of district police officers and the police as a whole; objective, systematic, timely and consistent information to the public about the state of the operational situation in the respective territory, the structure, level and dynamics of crime.

Key words: interaction with other entities of prevention, interaction with the population on the basis of partnership, publicity, humanism, police officer, law, scientific management, planning, respect for the individual, political neutrality, predictability, principles of preventive activity, social justice, about efficiency. 